\title{
Gothicism in The Fall of the House of Usher
}

\author{
Wenfang Pang, Diqiu Wang, Shanshan Hu \\ Air Force Logistics College, Xuzhou, China \\ Email: 1261169804@qq.com
}

Received 27 December 2014; accepted 15 January 2015; published 22 January 2015

Copyright (C) 2015 by authors and Scientific Research Publishing Inc.

This work is licensed under the Creative Commons Attribution International License (CC BY).

http://creativecommons.org/licenses/by/4.0/

c) (i) Open Access

\begin{abstract}
Edgar Allan Poe is one of the most unique writers in America. He stands alone with his aesthetic taste and writing principle, engaged in the morbid theme of nightmare, death, crime and evil. Consequently, he adopts Gothic technique in a composition, taking a full advantage of Gothic subject matter, plot and elements and lingering on violence, murder, insanity and collapse. The Fall of the House of Usher is Poe's classical piece of this type. It presents terrifying atmosphere, the dark plot, and man's psychological terror to reveal the process of disintegration and annihilation of human mind, thus offering readers specific aesthetic perception through psychological shocks. This paper borrowing a critical perspective of Gothic tradition and theory of the sublime, tries to analyze the Gothicism in this novel to detect its aesthetic feature.
\end{abstract}

\section{Keywords}

\section{Gothic, Horror, Sublime, Aesthetic Function}

\section{Introduction}

Gothic Stories are romantic tales of terror and the supernatural, which rely a great deal on scene and setting to convey a sense of horror to the reader. The American author Edgar Allen Poe (1809-1849) is just one master of the literary genre known as the Gothic story, and he makes great contribution to Gothic fiction. He inherits and develops the tradition Gothic fiction, and the American literature forms the background of his horror fictions and gives his fictions unique power and charm. To a certain degree, Poe's horror fiction prepares the origin of Southern fiction. In his works, he reveals people's horror towards super nature, nothingness, death, evil and disintegration of personality. He tries to make it clear that horror comes from our soul. He tries his best to state how the evil and horror function in bringing the sublimation and purification to man's inner world.

The Fall of the House of Usher written by Edgar Allan Poe in 1839 is regarded as an early and supreme example of the Gothic horror story, and it has the usual Gothic elements found in most works by Poe. Every aspect expected from a Poe's piece can be found within this story. What's more, just as his other excellent works, Poe 
not only tells a story, but also clarifies his spirit in this work: Horror is a kind of instinct and one of the strongest feelings of human kind. At the same time, according to the theory of sublime by Longinus, Imanuel Kant and Burke, readers still can find beauty from horror in Gothic fiction and experience the aesthetic pleasure.

Through an analysis of related knowledge with Gothic and his works which have fascinated readers of generations with its unique artistic beauty, this paper will highlights Poe's fiction and proves that his works merit our discussion.

\section{Gothic Literature and Edgar Allan Poe}

The Gothic literature's development is very colorful and the influence is great, because the Gothic has devoted itself to many popular genres and influenced many important writers such as Edgar Allan Poe. Poe, as one of the most important writers in American Southern literature, makes very important contribution to the development of the Gothic literature.

\subsection{Development of Gothic Novel}

First, if we were going to focus on the Gothic literature, we should understand the definition of the term "Gothic".

It comes from the word "Goth", which indicates one of several Germanic tribes that was instrumental in the fall of the Roman Empire in the medieval times. Confirmed by the archaeologists, their early settlement was in the Baltic, and gradually they migrated down to the Black Sea. During the third century, the Goths made their incursion into Roman and in AD 410, they took Rome under King Alaric and established kingdoms in France and Italy. Therefore, the Goths has long left people with the indelible image of truculence, barbarian and gracefulness. What's more, sometimes the word is even used to frighten children.

The Myths about the tribe are much more important than any history of the actual Goths, who are remembered only as invaders and destroyers of the great Roman civilization since no literature or art of their own has been left. Following the fall of Rome, very little has been known about the medieval world during the Renaissance, when the idea of the "Dark Ages" expanded to include the period, and "Gothic" (Cavallaro, 2002) became a term applied to all things medieval.

In some dictionary, "Goth" is defined as one not civilized, deficient, a barbarian and the medieval or "Gothic" age as a cultural wasteland, primitive and superstitious. The term was first used in an aesthetic sense, i.e. a style of architecture of the Germanic tribe. Its typical characteristics are long and narrow corridor and somber castle always with basement for corpses and so on. As a result, the style has been erroneously identified as barbaric, disorder and irrational opposite to the classic One.

In literary sense, it is clearly possible to speak of the Gothic as a historical phenomenon, originating in the late eighteenth century (Mao, 2006).

From the "Goth" tribe to the special genre "Gothic novel" and with the development of "Gothic novel", it proves that this kind of literature merits lots of authors to devote themselves to, and it has made and will continue to do a lot to itself and other genres.

\subsection{Gothic Literature in American Literature}

Gothic literature has great development in America. What's more, the American Gothic, the exploration of dark psychology and the flourishing of Gothic tales tell us that American Gothic is more than an offshoot of the European Gothic. However, at the beginning, American gothic works just tend to transform European Architecture into American landscape as material as intriguing.

With the development of the Gothic works in America, three authors define a black thread in American literature that while not entirely original (borrowing from European Gothicism and certain American precursors) is perfected in their works and continues to show its form in subsequent literature both American and European. These authors are Washington Irving, Nathaniel Hawthorne, and Edgar Allen Poe. At that moment, American gothic had new features. It has the exploration and expression of the different human psychology, and another contribution to the Gothic literature is to extend it from the dominant form of novel to the short story. We can get this point clearly in the works of Poe and Hawthorne, and this point is inherited successfully and enriched by William Faulkner and Flannary O’ Connor who have given a new power of the Gothic. 
In the soil of America, Gothic literature is poured into fresh blood and lots of excellent Gothic works emerge, and the American literature becomes much more abundant.

\subsection{Poe and His Gothic Novels}

In the literature history of America, Poe is one of the most unique writers. His creative technique and literary theories are totally different from the main stream in the field of literature in his times. However, Poe had been misunderstood by readers and his contemporaries for quite a long time. It was until 20th century that the importance of Poe's literary creations had been recognized by the academic world.

Nowadays, Poe has been recognized by the whole world as the precursor of modernistic writings, originator of the short stories, forerunner of psychoanalytic criticism and father of modern detective stories. What's more, he enjoys a very important status in American literary history and achieves great achievement in both pure and popular literature. Poe stands between them to keep the balance and exert some sound influences in both directions.

We can't deny that Poe is a great author in America and his devotion to the Gothic novels is huge, and his Gothic fiction has a unique position in the literary history.

\section{Analysis of Gothic Elements in The Fall of the House of Usher}

Before you begin to format your paper, first write and save the content as a separate text file. Keep your text and graphic files separate until after the text has been formatted and styled. Do not use hard tabs, and limit use of hard returns to only one return at the end of a paragraph. Do not add any kind of pagination anywhere in the paper. Do not number text heads - the template will do that for you.

Finally, complete content and organizational editing before formatting. Please take note of the following items when proofreading spelling and grammar:

\subsection{Analysis of Atmosphere}

Gothic atmosphere is very important for representing its dark feature for Gothic tales. The traditional Gothic atmosphere is always located in ruined castles and abbeys, and has dark passages and stairwells echoing with howls, groans and dripping charnel houses which come from the Gothic architecture, which bloomed in the 12th to the 16th century. And the use of the atmosphere is very simple, but the atmosphere emerged in Poe's works is diversity.

In The Fall of the House of Usher, the atmosphere is used extensively to do many things. The author uses it to convey ideas, effects, and images. It establishes a mood and foreshadows future events. Poe communicates truths about the character through atmosphere. Symbols are also used throughout to help understand the theme through the atmosphere.

Poe creates an atmosphere in the reader's mind. He chose every word in every sentence carefully to create a gloomy mood. For example, Usher's house, its windows, bricks, and dungeon are all used to make a dismal atmosphere. The "white trunks of decayed trees," the "black and lurid tarn," and the "vacant, eyelike windows" contribute to the collective atmosphere of despair and anguish (Edgar Allan Poe, 1982).

This is done with the words black, lurid, decayed, and vacant. The narrator says that the Usher mansion had "an atmosphere which had no affinity with the air of heaven." (Hayes, 2004). It was no where near being beautiful, holy, or clean. He uses descriptive words such as decayed, strange, peculiar, gray, mystic, gothic, pestilent, dull and sluggish to create the atmosphere. Poe's meticulous choice of words creates a very effective atmosphere in the story.

Through the atmosphere, Edgar Allan Poe is able to foreshadow events, and reveal character traits. Although the reader may not notice all the numerous devices used, they contribute to giving the story depth. Noticed or not, Poe utilizes the atmosphere to its full capacity to create the mood, characters and foreshadowing.

\subsection{Analysis of Characterization}

The Gothic characters portray in Poe's works are unique and excellent. Many of them emerged with a fear for death: someone is already mad or someone wants to be away from the incipient madness just as Roderick Usher in The Fall of the House of Usher. What's worse, some others are striving to come back from the tomb like Ma- 
delin, in fact, who is buried alive. Unlike those archetypal hero-villain who are popular in traditional Gothic literature, Poe's characters are mostly victimized, either by the dark psycho that "do wrong only for wrong's sake", or the terror that roots in his inner fear. The most victimized character in Poe's fiction is no doubt Roderick Usher, and Poe describes him like this:

A cadaverousness of complexion, an eye large, liquid, a luminous beyond comparison; lips somewhat thin and very pallid, but of surpassingly beautiful curve; a nose of a delicate Hebrew mode..., a fine moulded chin, ... in its want of prominence... (Chang, 2002)

As someone has said, what the writer described about the Roderick Usher is very similar with Poe himself. If this is true, maybe we can judge that the role in the novel still reflects Poe's world. What's more, the reason that the narrator finds everything within his room in House of Usher, such as the black oaken floor, the dark drapery and the general furniture which are "profuse, comfortless, antique and tattered", makes an unspeakable sense of familiarity and gives us what the environment like in Poe's own inner world.

He is afraid of this kind of feeling and suffers bitterly by his inner fear for the result which is caused by his inner horror and secret sin, but the narrator could not need to consider about these. So, at the first sight of his ever intimate companion in early boyhood, he connects its Arabesque expression with any idea of simple humanity.

His special fear affects everything no matter in mind and without, from the guest and the House itself and the tarn beyond. It explains the result of the tale naturally that the collapse of Usher's reason makes the fall of his house. It is the special collapse of character's mind that made the realistic things has the same result.

\subsection{Analysis of Symbol}

As we all know, symbol in literature can be defined as something you can see that has taken on a meaning beyond itself or a visible object or action that suggests some further meaning, in addition to itself.

From The Fall of the House of Usher, we can have a conclusion that the Usher family is the symbol of the final production of the highly sensitive civilization, it is destined to be buried under the ground by horror. The tarn and canvas symbolize evil, the malaria symbolizes super nature and illusion, horror lies in evil and madness, death finally defeat goodness, sense and life, and everything vanish in deathly stillness. The house of Usher can be regarded as the body of Roderick Usher, the gloomy inside of the house symbolize the illusion in his mind, the whole novel can be taken as "a journey to the depth of self", and the hero Roderick is the metaphor of "hypnosis of the brain" (Xiao, 2005).

The uncertain symbols cast a veil on Poe's works and leave a huge space of imagination for the readers and trap them into the horrible atmosphere when they search for the symbolic meaning of the novel.

\section{Aesthetic Function of Gothicism}

This part is to discuss the charm of Poe's Gothic fictions on aesthetic. Sometimes, Poe's Gothic fictions show us a method that is not easy and harmful to be accepted by the readers to adjust their physical and psychological balance. But we have to admit that in Poe's Gothic fictions, horror and ugliness grasp our aesthetical vision. In the parts about horror and evil, Poe achieves the aesthetical functions of sublimation and purification of human morality and spirit.

\subsection{Horror Brings Sublimity}

First, we focus on the analysis on sublimation given by Poe in The Fall of the House of Usher which expresses the beauty of astonishment:

The impetuous fury of the entering gust nearly lifted us from our feet. It was, indeed, a tempestuous yet sternly beautiful night, and one wildly singular in its terror and its beauty...did not prevent our perceiving the life-like velocity with which they flew careering from all points against each other, without passing away into the distance (Chang, 2002).

Horror, danger, pain and death are the psychological and aesthetic effects that Poe's Gothic fictions always want to have. One also feels a certain special painful pleasure and beneficial judge of morality and value from 
the horror and mercy cause by them, which always enlighten and educate people and make people face the internal himself.

Poe wants to show us through his stories that there should be a proper place for the irrational instinct and impulse, but we should be careful to keep them in harmony with our sense. Conflicts should be avoided, and if we refuse this kind of ideas, we will fall into the dark world. When we can avoid the extreme behavior or adopt the proper method to deal with it, we can get some benefit and achieve a collection of freedom. Once the readers keep an aesthetic distance with Poe's Gothic fictions, they can experience the "astonishment" produced by horror.

In Poe's Gothic fictions, the horror is turned into beauty after the terrible experience, and pain is turned into peaceful delight after aesthetics. This is the biggest aesthetic pleasure brought to us by horror in his works.

\subsection{Gothicism Brings Purification of Human Soul}

Gothic fiction is a special kind of literature. It can convince people to believe that there is nothing to be afraid of. It wakes up the terror in our soul and then turn it into an pleasure experience. The mixture of horror and pleasure enter our soul and purify us.

Gothic fiction exposes various horrible elements hidden in our everyday life: the pain of loss, the mystery of death, the unpredictability and inefficiency of the occurrence of events. Just because horror is one part of which we usually have in our daily life, though it sounds very strange to talk about daily life with the saying as horror. Although we don't know whether to laugh or cry, this expression on horror is effective to some degree. Because the daily life looks very natural and it has no depression of horror sometimes.

Gothic fictions describe the depressed horror in everyday life through show us the frightening elements of horror. This process is much like Freud's theory about dreams. Gothic fictions are a mixture that provide us charming beauty as well as the frightening horror.

Just as dreams can cure the depressed ideas of dreamer, the horror emerged in fictions could make the readers experience some imaginary life. But it should not too cruel, because if the tales make them feel too painful and too terrible that they will close the book.

In the fictions which are full of horror, although we are afraid of the threatening in our mind but its danger to our bodies, we know it clearly that it will not be met in real life. In other word, under the condition of no real danger, Gothic fiction creates lots of horrible scenes which bring a strong thrill to people and make people feel safe while experiencing the extreme danger and death. People are provided with a particular relaxation and pleasure. That is where the endless charm of Gothic fiction lies in.

As we all know, the horror in real life is terrible and can not produce pleasure. But in Poe's Gothic stories, a horrible frightening will emerge suddenly without any psychological preparation, and at the same time it can produce the huge delight or great pleasure. In other word, our hearts will be filled with some exaggerated excitement make by this kind of sudden horror.

This aesthetic pleasure is some kind of pleasure in our internal sense. Simply, maybe we can feel great pleasure from destruction. Everyone will have this experience which can be call "so cruel pleasure". The pain in the process of reading brings us the pleasure to validate our power (Yang, 2006).

To Poe himself, maybe he didn't want to write any external horror, because what he wanted to explore is the horror in everyone's heart. He tried his best to transfer the spiritual ties hidden in our unconsciousness into consciousness, then face them and deal with them. Finally, Poe's Gothic fictions make the courage and force to defeat horror in the readers' hearts and encourage people to face the real self bravely.

We can draw a conclusion that horror can bring people a stronger tragic aesthetic delight, which can urge people to get moral, correct mentality and purify morality, and at last make them achieve "goodness" or "virtue". So, the purpose of literature is to arouse people's emotion and let out people's horror, pain and mercy. We not only get the aesthetic pleasure from the horror and evil, but also a kind of "purification".

\section{Conclusion}

Edgar Allan Poe is a genius of imagination and verbal creation. He is a master skilled in manipulating language in his fictions as is the case of The Fall of the House of Usher to create the unique aesthetic effect he aims to achieve. His purpose for composition is to produce a feeling of beauty to bring "an elevating excitement of the soul”. In the given work discussed here, Poe offers different kinds of beauties: the beauty of horror, the beauty 
of love, and the beauty of death and despair. His pursuit of beauty labels him the first man who keeps to the principle of “Art for Art's sake.” Throughout his writing career, he pursues his aesthetic effect steadily at the cost of being ridiculed and wronged viciously by many. Among all the beauties presented in Poe's works, the beauty with Gothicism is most striking one.

In The Fall of the House of Usher, everything from atmosphere creation, character portrayal to the use of symbol shares one single purpose of creating Gothic horror to brings out the sense of sublimity for spiritual purification among readers. Kevin J. Hayes, the expert on Poe study once concludes, 'the word 'aesthetic' and its cognates have clung to the name of Edgar Allan Poe.” This is the right comment for Poe's principle of composition.

To sum up, aesthetic theory about the beauty of horror is successfully incarnated in Poe's Gothic fictions like The Fall of the House of Usher and Poe is creditably a giant in Gothic literature. An analysis of Poe's use of Gothicism is helpful for readers to appreciate the special aesthetic charm of his work.

\section{References}

Cavallaro (2002). The Gothic Vision Three Centuries of Horror Terror and Fear. London: MPG Books Ltd.

Chang, Y. X. (2002). Selected Readings in American Literature. Tianjin: Nankai University Press.

Hayes, K. J. (2004). The Cambridge Companion to Edgar Allan Poe. Shanghai: Shanghai Foreign Language Education Press.

Mao, X. D. (2006). A History of American Fiction. Hangzhou: Zhejiang University Press.

Poe, E. A. (1982). The Tell Tale Heart and Other Writings by Edgar Allen Poe. New York: Bantam Books.

Xiao, M. H. (2005). Selected Gothic Stories by Edgar Allan Poe. Chengdu: Sichuan People Press.

Yang, S. G. (2006). Sigmund FREUD. Translated by Psychology Philosophy. Beijing: Jiuzhou Press. 
Scientific Research Publishing (SCIRP) is one of the largest Open Access journal publishers. It is currently publishing more than 200 open access, online, peer-reviewed journals covering a wide range of academic disciplines. SCIRP serves the worldwide academic communities and contributes to the progress and application of science with its publication.

Other selected journals from SCIRP are listed as below. Submit your manuscript to us via either submit@scirp.org or Online Submission Portal.
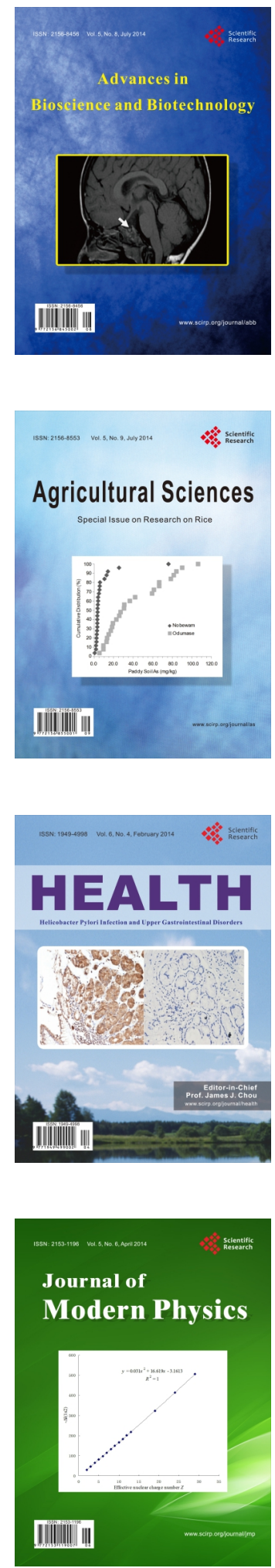
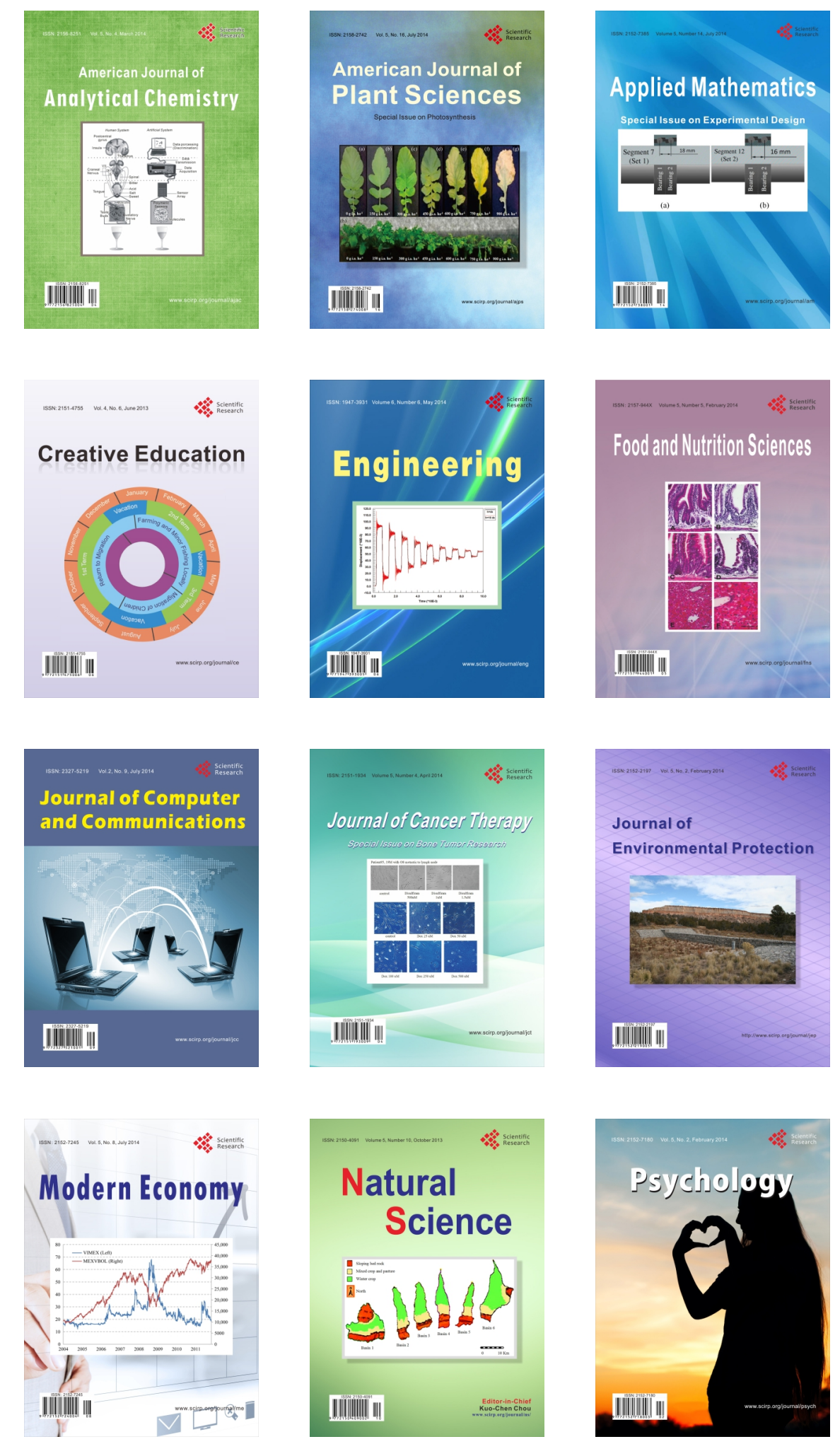